\title{
PENGARUH DISIPLIN KERJA DAN KOMPENSASI TERHADAP KINERJA BADAN KEPEGAWAIAN DAN PENGEMBANGAN SDM KABUPATEN MUSI BANYUASIN
}

\author{
Desi Ulpa Anggraini \\ Desiulpa09@gmail.com \\ Yeni Marsih \\ marsihyeni@gmail.com
}

Sekolah Tinggi Ilmu Ekonomi Rahmaniyah Sekayu

\begin{abstract}
ABSTRAK
Penelitian ini bertujuan, untuk : 1) Mengetahui Pengaruh Disiplin Kerja Terhadap Kinerja Pegawai Badan Kepegawaian dan Pengembangan SDM Kabupaten Musi Banyuasin 2) Mengetahui Pengaruh Kompensasi Terhadap Kinerja Pegawai Badan Kepegawaian dan Pengembangan SDM Kabupaten Musi Banyuasin. 3) Mengetahui Pengaruh Disiplin Kerja dan Kompensasi secara simultan Terhadap Kinerja Pegawai Badan Kepegawaian dan Pengembangan SDM Kabupaten Musi Banyuasin. Populasi dalam penelitian ini 41 orang diambil menggunakan rumus slovin sehingga sampel penelitian didapat sebanyak 37 orang. Jenis data yang digunakan dalam penelitian ini adalah data primer dan data sekunder. Teknik pengumpulan data yang digunakan adalah kuesioner. Analisis data yang digunakan adalah analisis regresi linier berganda. Hasil penelitian menunjukkan bahwa dari perhitungan $\mathrm{F}_{\text {-hitung }}$ $(8.752)>\mathrm{F}_{\text {-tabel }}(3,28)$ dan t- hitung untuk variabel $\mathrm{X}_{1}$ yakni disiplin kerja adalah sebesar $(2,780)$ dan untuk variabel X2 yakni kompensasi adalah sebesar $(2,419)>t$ tabel $(1,687)$. Dari Hasil penelitian didapat hasil $t_{\text {hitung }}$ untuk variabel $X_{1}$ yakni disiplin kerja adalah sebesar 2,780 > dari $\mathrm{t}_{\text {tabel }} 1.687$ maka $\mathrm{H}_{0}$ ditolak dan $\mathrm{H}_{1}$ diterima yang berarti bahwa terdapat pengaruh disiplin kerja terhadap kinerja pegawai Badan Kepegawaian dan Pengembangan SDM Kabupaten Musi Banyuasin.

Dari hasil penelitian diperoleh nilai t hitung Untuk variabel $\mathrm{X}_{2}$ yakni kompensasi adalah sebesar 2,419 > dari t tabel 1,687 maka $\mathrm{H}_{0}$ diterima dan $\mathrm{H}_{1}$ ditolak yang berarti bahwa berpengaruh variabel $\mathrm{X}_{2}$ yakni kompensasi terhadap kinerja pegawai di Badan Kepegawaian dan Pengembangan SDM Kabupaten Musi Banyuasin. Dari Hasil penelitian didapat hasil Fhitung (F-statistic) sebesar 8,752 karena $\mathrm{F}_{\text {hitung }}$ lebih besar dari $\mathrm{F}_{\text {tabel }}$ yaitu 3,28 dengan nilai probabilitas 0,001 yang berarti dibawah nilai signifikansi 0,05 , maka, $\mathrm{H}_{0}$ ditolak dan $\mathrm{H}_{3}$ diterima yang berarti variabel independen disiplin kerja dan kompensasi secara simultan (bersama sama) memiliki pengaruh terhadap kinerja Pegawai. Berarti $\mathrm{H}_{0}$ ditolak dan $\mathrm{H}_{\mathrm{a}}$ diterima yang artinya terdapat pengaruh disiplin kerja (X1), kompensasi (X2) terhadap kinerja pegawai (Y), baik secara simultan maupun persial.
\end{abstract}

Kata Kunci : Disipli Kerja, Kompensasi, dan Kinerja Pegawai.

\subsection{Latar Belakang Penelitian}

Kinerja pegawai menurut Sutrisno (2016 : 172) “Kinerja adalah hasil kerja Pegawai dilihat dari aspek kualitas, kuantitas, waktu kerja, dan keja sama untuk mencapai tujuan yang telah ditetapkan oleh organisasi”.

Menurut Sutrisno (2014 : 86), disiplin adalah sikap kesediaan seseorang untuk mematuhi dan menaati norma - norma peraturan yang berlaku disekitarnya. Disiplin pegawai yang baik akan mempercepat pencapaian tujuan perusahaan, sedangkan ketidakdisiplinan akan menjadi penghalang dan memperlambat pencapaian tujuan perusahaan.

Permasalahan kinerja pegawai yang disebabkan oleh kurang disiplin dan Ketidakpuasan kompensasi juga dialami oleh Badan Kepegawaian dan Pengembangan 
SDM Kabupaten Musi Banyuasin. Badan Kepegawaian dan Pengembangan SDM Kabupaten Musi Banyuasin beralamat di Jalan Kolonel Wahid Udin Kelurahan Balai Agung Sekayu. Telp. (0714) 321403.

Pengertian kompensasi menurut Handoko, (2010 : 155) adalah segala sesuatu yang diterima para pegawai sebagai balas jasa untuk kerja mereka. Pemberian kompensasi merupakan salah satu pelaksanaan fungsi manajemen sumber daya manusia yang berhubungan dengan semua jenis pemberian penghargaan individual sebagai pertukaran dalam melakukan tugas organisasi. Berdasarkan teori tersebut maka dapat diketahui bahwa kompensasi berperan penting di dalam sebuah perusahaan. Dengan adanya kompensasi, pegawai bisa memenuhi semua kebutuhannya serta berdampak baik pula pada kinerja pegawai.

Berdasarkan hasil laporan SKP (Sasaran Kinerja Pegawai) beberapa tahun terakhir mengalami fluktuasi dalam pencapaian target kerja. Dalam pengumpulan tugas pun terkadang ada beberapa pegawai yang telat dalam pengumpulannya. Dalam pengerjaan tugas pun ada beberapa pegawai yang mengalihkan atau meminta bantuan rekan kerjanya dalam menyelesaikan tugas tersebut dan itu berpengaruh terhadap tugas - tugas yang lainnya. Dari hasil temuan penulis permasalahan kinerja ini disebabkan penerapan disiplin kerja belum optimal, dimana masih ada pegawai yang belum mentaati disiplin kerja seperti : pada masa pandemi covid-19 sudah ada jadwal WFH (Work From Home) dan WFO (Work From Office) yang dilaksanakan di kantor Badan Kepegawaian dan Pengembangan SDM masih saja tidak hadir dan menjadi kebiasaan yang dilakukan oleh pegawai. Tentunya hal ini tidak sejalan dengan jam kerja setiap hari yang harus dilakukan oleh pegawai secara efektif adalah $\geq 7,5 \mathrm{Jam}$. Namun pada kenyataannya ada beberapa pegawai yang masih bersikap tidak mematuhi jam kerja serta peraturan yang telah ditetapkan.Ini dapat dilihat berdasarkan data dari Sub Bagian Umum dan Kepegawaian yang meliputi data absensi dan pelanggaran jam kerja Pegawai Badan Kepegawaian dan Pengembangan SDM Periode Januari 2020 s.d Desember 2020. Penyajian ringkasan rekapitulasi data dapat dilihat pada tabel 1.1 berikut.

Tabel 1.1

Kehadiran Pegawai Negeri Sipil Pada Januari s.d Desember 2020

\begin{tabular}{|c|c|c|c|c|c|}
\hline \multirow{2}{*}{ Bulan } & \multirow{2}{*}{$\begin{array}{l}\text { Jumlah } \\
\text { Pegawai }\end{array}$} & \multicolumn{2}{|c|}{ Status Kehadiran } & \multirow{2}{*}{$\begin{array}{c}\text { Tidak } \\
\text { Hadir }\end{array}$} & \multirow{2}{*}{ Total } \\
\cline { 3 - 4 } & & WFH & WFO & & 2 \\
\hline Januari & 41 & - & 39 & - & 41 \\
\hline Februari & 41 & - & 41 & - & 41 \\
\hline Maret & 41 & 30 & 11 & 2 & 41 \\
\hline April & 41 & 20 & 19 & 1 & 41 \\
\hline Mei & 41 & 21 & 19 & - & 41 \\
\hline Juni & 41 & 21 & 20 & - & 41 \\
\hline Juli & 41 & 21 & 20 & 3 & 41 \\
\hline Agustus & 41 & 21 & 17 & 5 & 41 \\
\hline September & 41 & 21 & 15 & 1 & 41 \\
\hline Oktober & 41 & 21 & 19 & 2 & 41 \\
\hline November & 41 & 21 & 18 & 4 & 41 \\
\hline Desember & 41 & 21 & 16 & & \\
\hline
\end{tabular}

Sumber : Badan Kepegawaian dan Pengembangan SDM tahun 2020.

Berdasarkan tabel 1.1 diatas menggambarkan kehadiran PNS Badan Kepegawaian dan Pengembangan SDM yang datang terlambat dan pulang awal pada Januari - Desember 2020 adalah sebanyak 41 orang (jumlah keseluruhan PNS BKPSDM MUBA), dari tabel di atas dapat dilihat bahwa Pegawai Negeri Sipil Badan Kepegawaian dan Pengembangan SDM yang tidak hadir masih terjadi setiap bulannya walaupun jumlahnya berfluktuasi. 
Berdasarkan uraian diatas, penulis tertarik untuk meneliti mengenai "Pengaruh Disiplin Kerja dan Kompensasi Terhadap Kinerja Badan Kepegawaian dan Pengembangan SDM Kabupaten Musi Banyuasin".

\subsection{Rumusan Masalah}

1. Adakah Pengaruh Disiplin Kerja Terhadap Kinerja Pegawai Badan Kepegawaian dan Pengembangan SDM Kabupaten Musi Banyuasin?

2. Adakah Pengaruh Kompensasi Terhadap Kinerja Pegawai Badan Kepegawaian dan Pengembangan SDM Kabupaten Musi Banyuasin?

3. Adakah Pengaruh Disiplin Kerja dan Kompensasi secara simultan terhadap Kinerja Pegawai Badan Kepegawaian dan Pengembangan SDM Kabupaten Musi Banyuasin?

\subsection{Tujuan Penelitian}

1. Untuk mengetahui Pengaruh Disiplin Kerja Terhadap Kinerja Pegawai Badan Kepegawaian dan Pengembangan SDM Kabupaten Musi Banyuasin.

2. Untuk mengetahui Pengaruh Kompensasi Terhadap Kinerja Pegawai Badan Kepegawaian dan Pengembangan SDM Kabupaten Musi Banyuasin.

3. Untuk mengetahui Pengaruh Disiplin Kerja dan Kompensasi secara simultan Terhadap Kinerja Pegawai Badan Kepegawaian dan Pengembangan SDM Kabupaten Musi Banyuasin.

\subsection{Metodologi Penelitian}

\subsubsection{Lokasi dan Waktu Penelitian}

Penelitian ini dilakukan pada Badan Kepegawaian dan Pengembangan SDM Kabupaten Musi Banyuasin terletak di Jalan Kolonel Wahid Udin Kelurahan Balai Agung Sekayu. Telp.(0714) 321 403. Penelitian ini telah dilaksanakan selama 5 bulan.

\subsubsection{Jenis Penelitian}

Dalam penelitian ini, penulis menggunakan jenis Asosiatif karena penelitian ini bertujuan untuk mengetahui hubungan antara dua variabel atau lebih. Dalam hal ini variabel yang dimaksud adalah Variabel Disiplin, Variabel Kompensasi, dan Variabel Kinerja Pegawai.

\subsubsection{Jenis Dan Sumber Data}

Data yang digunakan dalam penelitian ini adalah data primer, yang berupa jawaban kuesioner yang diedarkan kepada para pegawai.

\subsubsection{Populasi dan Sampel}

Populasi dalam penelitian ini adalah seluruh Pegawai Negeri Sipil Badan Kepegawaian dan Pengembangan SDM Kabupaten Musi Banyuasin sebanyak 41 orang. Sampel yang digunakan dalam penelitian ini adalah 37 sampel diambil menggunakan rumus slovin.

\subsubsection{Teknik Pengumpulan Data}

Metode pengumpulan data yang digunakan dalam penelitian ini adalah penelitian ini adalah kuesioner, wawancara dokumentasi.

\subsubsection{Operasionalisasi Variabel}

\section{Tabel 1.2}

\section{Definisi Operasionalisasi Variabel}

\begin{tabular}{|c|c|c|c|c|}
\hline Variabel & Definisi & Indikator & $\begin{array}{l}\text { Item } \\
\text { Prtyn }\end{array}$ & Skala \\
\hline $\begin{array}{c}\text { Disiplin Kerja } \\
\text { (X1) }\end{array}$ & $\begin{array}{l}\text { Sikap kesediaan pegawai Badan } \\
\text { Kepegawaian dan Pengembangan } \\
\text { SDM Kabupaten Musi Banyuasin } \\
\text { untuk mematuhi dan menaati norma- } \\
\text { norma peraturan yang berlaku di } \\
\text { Badan Kepegawaian dan } \\
\text { Pengembangan SDM Kabupaten } \\
\text { Musi Banyuasin. }\end{array}$ & $\begin{array}{l}\text { 1. Penggunaan waktu } \\
\text { secara efektif. } \\
\text { 2. Ketaatan terhadap } \\
\text { peraturan yang telah } \\
\text { ditetapkan. } \\
\text { 3. Tanggung jawab dalam } \\
\text { pekerjaan dan tugas. }\end{array}$ & $1-3$ & Likert's \\
\hline
\end{tabular}




\begin{tabular}{|c|c|c|c|c|}
\hline Variabel & Definisi & Indikator & $\begin{array}{l}\text { Item } \\
\text { Prtyn }\end{array}$ & Skala \\
\hline & Menurut Sutrisno , $(2011: 94)$ & & $9-10$ & \\
\hline $\begin{array}{l}\text { Kompensasi } \\
\text { (X2) }\end{array}$ & $\begin{array}{l}\text { Sesuatu yang diterima pegarisnowai } \\
\text { Badan Kepegawaian } r \text { dan } \\
\text { Pengembangan SDM Kabupaten } \\
\text { Musi Banyuasin atas jasa yang } \\
\text { mereka sumbang kan pada } \\
\text { pekerjaannya. } \\
\text { Menurut Ernie }(2007: 223)\end{array}$ & $\begin{array}{l}\text { 1. Kompensasi Finansial } \\
\text { A. Kompensasi langsung } \\
\text { a) Gaji \& Upah } \\
\text { b) Tunjangan } \\
\text { c) Bonus \& Komisi } \\
\text { B. Kompensasi tidak } \\
\text { langsung } \\
\text { a) Asuransi Kesehatan } \\
\text { b) Cuti Tahunan } \\
\text { 2.Kompensasi Non Finansial } \\
\text { a) Pekerjaan } \\
\text { b) Lingkungan Pekerjaan }\end{array}$ & $1-4$ & Likert's \\
\hline Kinerja (Y) & $\begin{array}{l}\text { Kinerja adalah hasil kerja yang } \\
\text { dicapai oleh seseorang atau kelompok } \\
\text { orang dalam suatu organisasi, sesuatu } \\
\text { dengan wewenang dan tanggung } \\
\text { jawab masing -masing dalam rangka } \\
\text { upaya mencapai tujuan organisasi } \\
\text { bersangkutan, secara legal tidak } \\
\text { melanggar hukum dan sesuai dengan } \\
\text { moral maupun etika. } \\
\text { Hasibuan, (2009:39) }\end{array}$ & $\begin{array}{l}\text { 1. Kuantitas } \\
\text { 2. Kualitas } \\
\text { 3. Personality } \\
\text { 4. Ketepatan waktu }\end{array}$ & $\begin{array}{c}1-3 \\
4-6 \\
7-8 \\
9-10\end{array}$ & Likert's \\
\hline
\end{tabular}

\subsubsection{Teknik Analisa Data}

\section{Analisis Data}

a. Analisis Kualitatif adalah analisis yang tidak menggunakan model matematika, model statistik dan ekonometrik atau model - model tertentu lainnya.

b. Analisis Kuantitatif adalah data yang berbentuk angka atau data kualitatif yang diangkat/scoring. Secara kualitatif, data yang akan diolah adalah jawaban responden yang penentuan alternatifnya menggunakan skala likert, sebagai berikut:

2. Uji Instrumen

a. Uji validitas

Uji validitas digunakan untuk mengetahui kelayakan butir - butir dalam suatu daftar pernyataan dalam mendefinisikan suatu variabel. Hasilnya akan ditunjukkan oleh nilai corrected item-total correclation dengan taraf signifikan 5\% jika $\mathrm{r}$ tabel $<\mathrm{r}$ hitung makan instrumen dinyatakan valid. Uji validitas dapat dilakukan skor total yang merupakan jumlah skor tiap butir, dengan rumus product moment.

b. Uji Reliabilitas

Uji reliabilitas merupakan ukuran suatu kestabilan dan konsistensi responden dalam menjawab hal yang berkaitan dengan konstruk - konstruk pertanyaan yang merupakan dimensi suatu variabel dan disusun dalam suatu bentuk kuesioner. Uji reliabilitas dapat dilakukan secara bersama - sama terhadap seluruh butir pertanyaan. Hasil uji reliabilitas menunjukkan bahwa alat ukur yang digunakan reliabel apabila nilai Alpha Cronbach $>0.60$ maka instrumen dinyatakan reliabel.

3. Uji Asumsi Klasik

a. Uji Normalitas

Uji normalitas data dimaksudkan untuk memperlihatkan bahwa data sampel berasal dari populasi yang berdistribusi normal. Ada beberapa teknik yang dapat digunakan untuk menguji normalitas data, antara lain uji kolmogorov-smirnov. Adapun untuk menguji normalitas penulis menggunakan kolmogorov-smirnov. 
Adapun intepretasi dalam pengujian normalitas kolmogorov-smirnov menurut Priyanto (2012 : 31), adalah jika nilai signifikan lebih besar dari 0,05 maka data tersebut berdistribusi normal. Sebaliknya jika nilai signifikansi lebih kecil dari 0,05 maka data tersebut tidak berdistribusi normal.

b. Uji Linieritas

1. Dengan melihat nilai signifikansi

1) Jika nilai signifikan $>0,05$, maka dapat disimpulkan bahwa terdapat hubungan linier secara signifikan antara variabel independen (X) dengan variabel independen $(Y)$.

2) Jika nilai signifikansi $<0,05$, maka dapat disimpulkan bahwa tidak terdapat hubungan linier secara signifikan antara variabel independen $(\mathrm{X})$ dengan variabel dependen $(\mathrm{Y})$.

2. Dengan melihat $\mathrm{F}$ hitung dan $\mathrm{F}$ tabel

1) Jika $\mathrm{F}$ hitung < Ftabel, maka dapat disimpulkan bahwa terdapat hubungan linier secara signifikan antara variabel independen $(\mathrm{X})$ dengan variabel dependen $(\mathrm{Y})$.

2) Jika $\mathrm{F}$ hitung $>\mathrm{F}$ tabel, maka dapat disimpulkan bahwa tidak terdapat hubungan linier secara signifikan antara variabel independen $(\mathrm{X})$ dengan variabel dependen $(\mathrm{Y})$.

c. Multikolinearitas

Tujuan uji Multikolinearitas adalah untuk melihat apakah pada model regresi ditemukan adanya kolerasi antar variabel bebas. Jika terjadi korelasi, maka dinamakan terdapat problem Multikolinearitas. Cara mendeteksinya adalah dengan melihat nilai Variance Inflation Factor (VIF). Menurut Santoso (2016 : 173), uji multikolinearitas bertujuan untuk menguji apakah dalam model regresi ditemukan adanya korelasi antara variabel bebas (independen).

d. Heterokedastisitas

Uji heterokedastistas berarti varians variabel independen adalah konstan atau sama untuk setiap nilai tertentu variabel independen (heterokedastistas). Model regresi yang baik adalah tidak terjadi heterokedastistas di uji dengan menggunakan kurva scatterplot nilai residual variabel dependen. Pengambilan

Teknik Analisis yang digunakan pada penelitian ini adalah regresi linier berganda. Menurut Santoso, (2016 : 155) regresi linier berganda adalah data pengamatan biasanya tidak hanya disebabkan oleh suatu variable seperti yang dicontohkan di atas melainkan oleh beberapa atau bahkan banyak variabel.

Persamaan regresi linier berganda :

Keterangan :

$$
\mathrm{Y}=\mathrm{a}+\mathrm{b}_{1} \mathrm{X}_{1}+\mathrm{b}_{2} \mathrm{X}_{2}+\mathrm{e}
$$

$\begin{array}{ll}\mathrm{Y} & =\text { Kinerja Pegawai } \\ \mathrm{A} & =\text { Konstanta } \\ \mathrm{b}_{1} \mathrm{~b}_{2} & =\text { Variabel } \mathrm{X}_{1} \mathrm{X}_{2} \\ \mathrm{X}_{1} & =\text { Kompensasi } \\ \mathrm{X}_{2} & =\text { Disiplin Kerja } \\ \mathrm{e} & =\text { error }\end{array}$

4. Uji Hipotesis

1. Pengujian Hipotesis Serentak/ Simultan (Uji F)

Ho $=$ Disiplin Kerja dan Kompensasi secara simultan tidak berpengaruh terhadap Kinerja Badan Kepegawaian dan Pengembangan SDM Kabupaten Musi Banyuasin.

$\mathrm{Ha}=$ Disiplin Kerja dan Kompensasi secara simultan berpengaruh terhadap Kinerja Badan Kepegawaian dan Pengembangan SDM Kabupaten Musi Banyuasin. 
(1) Taraf nyata yang digunakan $(\mathrm{a})=5 \%(0,05)$

(2) Nilai $F_{\text {tabel }}$ memiliki derajat bebas $(\mathrm{dkb})=\mathrm{n}-\mathrm{m}-1$ dan $(\mathrm{dka})=\mathrm{m}$

(a) Menentukan kriteria pengujian

Jika $\mathrm{F}_{\text {hitung }} \geq \mathrm{F}_{\text {tabel }} \leq \alpha$ maka $\mathrm{H}_{0}$ ditolak dan $\mathrm{H}_{\mathrm{a}}$ diterima.

Jika $\mathrm{F}_{\text {hitung }}<\mathrm{F}_{\text {tabel }} \mathrm{H}_{0}$ diterima dan $\mathrm{H}_{\mathrm{a}}$ ditolak.

(b) Menentukan Kesimpulan

Menyiapkan $\mathrm{H}_{0}$ diterima atau ditolak.

(1) $\mathrm{H}_{0}$ diterima dan $\mathrm{H}_{\mathrm{a}}$ ditolak secara simultan Artinya tidak ada pengaruh disiplin kerja dan kompensasi terhadap kinerja Badan Kepegawaian dan Pengembangan SDM Kabupaten Musi Banyuasin.

(2) $\mathrm{H}_{0}$ ditolak dan $\mathrm{H}_{\mathrm{a}}$ diterima Artinya tidak ada pengaruh disiplin kerja dan kompensasi terhadap kinerja Badan Kepegawaian dan Pengembangan SDM Kabupaten Musi Banyuasin.

5. Uji t (secara parsial)

$\mathrm{H}_{0}=$ Ada pengaruh disiplin kerja secara parsial terhadap kinerja Badan Kepegawaian dan Pengembangan SDM Kabupaten Musi Banyuasin.

$\mathrm{H}_{1}=$ Tidak ada pengaruh disiplin kerja secara parsial terhadap kinerja Badan Kepegawaian dan Pengembangan SDM Kabupaten Musi Banyuasin.

$\mathrm{H}_{0}=$ Ada pengaruh kompensasi secara parsial terhadap kinerja Badan Kepegawaian dan Pengembangan SDM Kabupaten Musi Banyuasin.

$\mathrm{H}_{2}=$ Tidak ada pengaruh disiplin kerja secara parsial terhadap kinerja Badan Kepegawaian dan Pengembangan SDM Kabupaten Musi Banyuasin.

\section{Menentukan taraf nyata $(\alpha)$ dan $t$ tabel}

(a) Taraf nyata yang digunakan $(\alpha)=5 \%(0,05)$

(b) Nilai t tabel memiliki derajat bebas $(\mathrm{db})=\mathrm{n}-2$ atau tabel $(\alpha / 2)$

(1) Menentukan kriteria Pengujian

Jika $t_{\text {hitung }} \geq \mathrm{t}_{\text {tabel }}$ maka $\mathrm{H}_{0}$ ditolak dan $\mathrm{H}_{\mathrm{a}}$ diterima.

Jika $t_{\text {hitung }}<\mathrm{t}_{\text {tabel }}$ maka $\mathrm{H}_{0}$ diterima dan $\mathrm{H}_{\mathrm{a}}$ ditolak.

1 Membuat Kesimpulan

(a) $\mathrm{H}_{0}$ diterima dan $\mathrm{H}_{\mathrm{a}}$ ditolak jika $t_{\text {hitung }}<\mathrm{t}_{\text {tabel. }}$. Artinya tidak ada pengaruh Disiplin Kerja dan Kompensasi secara parsial terhadap kinerja pada Badan Kepegawaian dan Pengembangan SDM Kabupaten Musi Banyuasin.

(b) $\mathrm{H}_{0}$ ditolak dan $\mathrm{H}_{\mathrm{a}}$ diterima jika $\mathrm{t}_{\text {hitung }} \geq \mathrm{t}_{\text {tabe. Artinya ada pengaruh }}$

Disiplin Kerja dan Kompensasi secara parsial terhadap kinerja pada Badan

Kepegawaian dan Pengembangan SDM Kabupaten Musi Banyuasin.

c. Koefesien Determinasi $\left(\mathrm{R}^{2}\right)$

Menurut Priyanto, (2010 : 66), analisis determinasi digunakan untuk mengetahui persentase sumbangan pengaruh variabel independen $\left(\mathrm{X}_{1}, \mathrm{X}_{2}, \ldots \ldots . \mathrm{X}_{\mathrm{n}}\right)$ secara serentak terhadap variabel dependen $(\mathrm{Y})$. Koefisien ini menunjukkan seberapa besar persentase variasi variabel dependen. $\mathrm{R}^{2}$ sama dengan 0 , maka tidak ada sedikit pun persentase sumbangan pengaruh yang diberikan variabel independen terhadap variabel dependen. Sebaliknya $\mathrm{R}^{2}$ sama dengan 1 , maka persentase sumbangan pengaruh yang diberikan variabel independen terhadap variabel dependen adalah sempurna.

\subsection{Konsep Teori}

\subsubsection{Pengertian Manajemen}

Menurut Griffin, (2010 : 5), manajemen adalah sebuah proses pengorganisasian, pengkoordinasian, perencanaan, dan pengontrolan sumber daya agar dapat mencapai sasaran (goals) secara efisien dan efektif. Efisien ialah dimana sebuah tugas yang ada telah dilaksanakan 
secara terorganisir, benar dan sesuai dengan schedule, sementara efektif sendiri berarti bahwa sebuah tujuan mampu dicapai sesuai dengan apa yang telah direncanakan.

Menurut Terry, (2011 : 11), manajemen adalah suatu proses unik dan khas yang terdiri atas tindakan-tindakan perencanaan, pengorganisasian, serta penggerakkan dan pengendalian yang dilakukan guna menentukan arah serta mencapai tujuan yang telah ditentukan sebelumnya melalui pemanfaatan SDM serta sumber daya lain.

\subsubsection{Pengawasan Manajemen Sumber Daya Manusia}

Menurut Handoko, (2011 : 4) Manajemen Sumber Daya Manusia adalah Penarikan, seleksi, pengembangan, pemeliharaan, dan penggunaan sumber daya manusia untuk mencapai baik tujuan - tujuan individu maupun organisasi.

Adapun fungsi - fungsi manajemen sumber daya manusia adalah:

a. Perencanaan

Perencanaan (human resources planning) adalah merencanakan tenaga kerja secara efektif serta efisien agar sesuai dengan kebutuhan perusahaan dalam membantu terwujudnya tujuan.

b. Pengorganisasian

Pengorganisasian adalah kegiatan untuk mengorganisasian semua pegawai

Dengan menetapkan pembagian kerja, hubungan kerja, delgasi wewenang,

integritas, dan koordinasi dalam bagan organisasi (organization chart).

c. Pengarahan

Pengarahan (directing) adalah kegiatan mengarahkan semua pegawai, agar mau bekerja sama dan bekerja efektif serta efisien dalam membantu tercapainya tujuan perusahaan, pegawai, dan masyarakat. Pengarahan dilakukan pimpinan dengan menugaskan bawahan agar mengerjakan semua tugasnya dengan baik.

d. Pengendalian

Pengendalian (controlling) adalah kegiatan mengendalikan semua pegawai, agar menaati peraturan - peraturan peru sahaan danbekerja sesuai dengan rencana.

e. Pengembangan

Pengembangan (development) adalah proses peningkatan keterampilan teknis, teoritis, konseptual, dan moral pegawai melalui pendidikan dan pelatihan.

f. Kompensasi

Kompensasi (compensation) adalah pemberian balas jasa langsung (direct) dan tidak langsung (indirect), uang atau barang kepada pegawai sebagai imbalan jasa yang diberikan kepada perusahaan.

g. Pengintegrasian

Pengintegrasian (integration) adalah kegiatan untuk mempersatukan kepentingan perusahaan dan kebutuhan pegawai, agar tercipta kerja sama yang serasi dan saling menguntungkan.

h. Pemeliharaan

Pemeliharaan (maintenance) adalah kegiatan untuk memelihara atau meningkatkan

Kondisi fisik, mental, dan loyalitas pegawai, agar mereka tetap mau bekerja sama sampai pensiun.

i. Kedisiplinan

Kedisiplinan merupakan fungsi manajemen sumber daya manusia yang terpenting dan kunci terwujudnya, tujuan, karena tanpa disiplin yang baik sulit terwujud tujuan yang maksimal.

j. Pemberhentian

Pemberhentian (separation) adalah putusnya hubungan kerja seseorang dari suatu perusahaan, pemberhentian ini disebabkan oleh keinginan pegawai, keinginan perusahaan, kotrak kerja berakhir, pensiun, dan sebab sebab lainnya. 


\subsection{Konsep Disiplin Kerja}

\subsubsection{Pengertian Disiplin Kerja}

Sutrisno, (2014 : 86) mengatakan disiplin adalah sikap kesediaan seseorang untuk mematuhi dan menaati norma - norma peraturan yang berlaku disekitarnya. Disiplin pegawai yang baik akan mempercepat tujuan perusahaan, sedangkan disiplin yang merosot akan menjadi penghalang dan memperlambat pencapaian tujuan perusahaan.

\subsubsection{Indikator - indikator Kedisiplinan}

Menurut Sutrisno, (2011 : 94) indikator disiplin kerja adalah sebagai berikut:

1. Taat terhadap aturan waktu. Hal ini dapat dilihat dari jam masuk kerja, jam pulang dan jam istirahat yang tepat waktu sesuai dengan aturan yang berlaku di perusahaan.

2. Taat terhadap peraturan perusahaan. Peraturan dasar tentang cara berpakaian, dan bertingkah laku dalam pekerjaan.

3. Taat terhadap aturan perilaku dalam pekerjaan. Ditunjukan dengan cara-cara melakukan pekerjaan-pekerjaan sesuai dengan jabatan, tugas dan tanggung jawab serta cara berhubungan dengan unit kerja lain.

4. Taat terhadap peraturan lainnya diperusahaan. Aturan tentang apa yang boleh dan apa yang tidak boleh dilakukan oleh para pegawai dalam perusahaan.

\subsubsection{Jenis - Jenis Disiplin Kerja}

Menurut Handoko, (2012: 208-211) membagi 3 Disiplin Kerja yaitu :

1. Disiplin Preventif

Disiplin Preventif adalah Kegiatan yang dilaksanakan untuk mendorong para pegawai agar mengikuti berbagai standar dan aturan, sehingga penyelewengan dapat dicegah.

2. Disiplin Korektif

Disiplin Korekti adalah : Kegiatan yang ambil untuk menangani pelanggaran terhadap aturan - aturan yang mencoba untuk menghindari pelanggaran - pelanggaran lebih lanjut. Kegiatan korektif sering berupa suatu bentuk hukuman dan disebut tingkatan pendisiplinan.

3. Disiplin Progresif

Disiplin Progresif adalah : Kegiatan memberikan hukuman - hukuman yang berat terhadap pelanggaran - pelanggaran yang berulang. Tujuan dari disiplin progresif ini agar pegawai dapat mengambil tindakan - tindakan korektif sebelum mendapat hukuman yang lebih serius.

\subsubsection{Faktor - Faktor Disiplin Kerja}

Disiplin Kerja merupakan sikap dan perilaku. Pembentukan perilaku jika dilihat dari Formula kurt Lewin adalah Interaksi antara faktor Kepribadian dan Faktor Lingkungan. Sarwanto (2016:21):

1) Disiplin Kerja faktor Kepribadian

Disiplin pada taraf ini yang penting adalah sistem nilai yang dianutnya. Nilai - nilai yang telah dianjurkan oleh orang tua, guru, dan lingkungannya ini akan dijadikan acuan untuk diterapkan di tempat kerja.

2) Disiplin Karena Faktor Kepatuhan

Kepatuhan terhadap aturan - aturan yang disarankan atas dasar perasaan takut. Disiplin kerja pada tingkatan ini dilakukan semata untuk mendapatkan reaksi positif dari pimpinan atau atas yang memiliki wewenang. Jika pimpinan tidak ada ditempat disiplin kerja tidak dampak.

3) Disiplin karena identifikasi

kepatuhan yang didasarkan pada identifikasi adalah adanya perasaan kekaguman atau penghargaan pada pemimpin.

4) Disiplin Karena Internalisasi 
Disiplin kerja dalam tingkat ini terjadi karena karyawan mempunyai sistem nilai pribadi yang menunjang tinggi nilai - nilai disiplin kerja. Pegawai pada tingkatan ini dapat dikategorikan telah mempunyai disiplin diri. Jika disiplin

dari telah terbangun pada pegawai pekerjaanya pun akan terasa ringan, karena karyawan sadar akan akan tanggung jawab yang telah dibebankan kepadanya.

5) Disiplin Faktor Lingkungan

Disiplin kerja yang tinggi akan muncul begitu saja tetapi merupakan suau proses belajar terus menerus.

\subsection{Konsep Kompensasi}

\subsubsection{Pengertian Kompensasi}

Menurut Imas, (2016 : 154) Kompensasi adalah sesuatu yang diterima pegawai atas jasa yang mereka sumbangkan pada pekerjaannya. Mereka menyumbangkan apa yang menurut mereka berharga, baik tenaga maupun pengetahuan yang dimiliki.

\subsubsection{Tujuan Kompensasi}

Menurut Suparyadi, (2015 : 275) menjelaskan bahwa" Tujuan utama pemberian kompensasi, yaitu untuk menarik pegawai yang berkualitas, mempertahankan pegawai memotivasi kinerja, membangun komitmen pegawai, dan satu hal yang sering kali terlupakan adalah mendorong peningkatan keahlian dan keterampilan pegawai dalam upaya meningkatkan kompetensi organisasi secara keseluruhan".

Menurut Sunyoto, (2014 : 156) Tujuan-tujuan yang hendak dicapai melalui administrasi kompensasi adalah:

1) Memperoleh Personalia yang Qualified

Kompensasi perlu ditetapkan cukup tinggi untuk menarik para pelamar. Karena perusahaan - perusahaan bersaing dalam pasar tenaga kerja tingkat pengupahan harus sesuai dengan kondisi penawaran dan permintaan tenaga kerja. Kadang-kadang tingkat gaji relatif tinggi diperlukan untuk menarik para pelamar cakap yang sudah berkerja di berbagai perusahaan lain.

2) Mempertahankan para Pegawai yang ada Sekarang

Jika tingkat kompensasi tidak kompetitif, maka banyak karyawan yang baik akan keluar. Untuk mencegah perputaran karyawan, pengupahan harus dijaga agar tetap kompetitif dengan perusahaan - perusahaan lain.

3) Menjaga Keadilan

Administrasi pengupahan dan penggajian berusaha untuk memenuhi prinsip keadilan. Keadilan atau konsistensi internal dan eksternal sangat penting diperhatikan dalam penentuan tingkat kompensasi.

4) Menghargai Perilaku Yang Diinginkan

Kompensasi hendaknya mendorong perilaku-perilaku yang diinginkan. Prestasi kerja yang baik, kesetiaan, tanggung jawab baru dan perilaku-perilaku lain dapat dihargai melalui rencana kompensasi yang efektif.

5) Mengendalikan Biaya-Biaya

Suatu program kompensasi yang rasional membantu organisasi untuk mendapatkan dan mempertahankan sumber daya manusia pada tingkat biaya yang layak.

6) Memenuhi Peraturan-peraturan Legal

Seperti aspek-aspek manajemen sumber daya manusia lainnya, administrasi kompensasi menghadap batasan-batasan legal. Program kompensasi yang baik memperhatikan kendalakendala tersebut dan memenuhi semua peraturan pemerintah yang mengatur kompensasi pegawai. 


\subsubsection{Indikator -indikator dalam Kompensasi}

Kompensasi merupakan cara perusahaan untuk meningkatkan kualitas pegawai untuk pertumbuhan perusahaan. Setiap kantor memiliki suatu sistem kompensasi yang berbeda - beda sesuai dengan visi, misi, dan tujuannya. Menurut Simamora, (2015:445) indikator pengukuran kompensasi terdiri dari :

a. Kompensasi Finansial

1.) Kompensasi langsung

a) Gaji dan Upah

b) Tunjangan

c) Bonus, komisi, dan pembagian keuntungan

2.) Kompensasi Tidak langsung

a) Program perlindungan yaitu asuransi kesehatan, asuransi jiwa, pension, dan asuransi tenaga kerja.

b) Bayaran di luar jam kerja yaitu liburan, hari besar, cuti tahunan, dan cuti hamil

b. Kompensasi Nonfinansial

1.) Pekerjaan yaitu tugas - tugas yang menarik, tantangan, tanggung jawab, pengakuan, dan rasa pencapaian

2.) Lingkungan kerja yaitu kebijakan yang sehat, surpervise yang kompeten, kerabat kerja yang menyenangkan, dan lingkungan kerja yang nyaman.

\subsubsection{Jenis - jenis Kompensasi}

Menurut Kismono, (2011: 178) terdapat 2 (dua) jenis kompensasi, yaitu :

1. Kompensasi Finansial

Kompensasi finansial ini sendiri dapat terbagi menjadi dua bagian yaitu kompensasi langsung dan kompensasi tidak langsung. Jenis kompensasi langsung adalah pembayaran upah (pembayaran atas dasar jam kerja), gaji (pembayaran tetap), dan insetif atau bonus. Sedangkan kompensasi tidak langsung adalah pemberian

pelayanan atau fasilitas kepada pegawai seperti program rekreasi, cuti, liburan, konseling, beasiswa pendidikan, dll

2. Kompensasi non Finansial

Kompensasi non finansial ini juga dapat terbagi menjadi 2 (dua) bagian, yaitu kepuasan dari pekerjaan itu sendiri dan kepuasaan yang didapat dari lingkungan kerja.

Tingkat kepuasan dari pekerjaan itu sendiri dapat berupa tugas yang menarik, tantangan, pengakuan, tantangan dan pencapaian. Sedangkan kepuasan dari lingkungan kerja dapat berupa kebijakan yang sehat, rekan kerja yang menyenangkan serta lingkungan kerja yang nyaman.

\subsubsection{Faktor - Faktor yang mempengaruhi Kompensasi}

Menurut Sunyoto (2014 : 158) Faktor - faktor yang mempengaruhi penetapan kompensasi , antara lain sebagai berikut :

1) Pendidikan, Pengalaman, dan Tanggungan

Ketiga faktor tersebut harus mendapatkan perhatian. Bagaimanapun juga tingkat upah seorang sarjana dari yang belum sarjana dari yang belum sarjana harus dibedakan, demikianpun antara yang berpengalaman dengan yang belum berpengalaman.

2) Kemampuan Perusahaan

Faktor ini dalam merealisasikan keadilan dalalm pembayaran upah belum berada dalam proporsi yang setepat - tepatnya. Jika perusahaan mengalami keuntungan, para pegawai harus turut menikmatinya melalui kenaikan tingkat upah atau pembagian keuntungan dan sebaliknya.

3) Keadaan Ekonomi

Keadaan ekonomi atau ongkos hidup adalah salah satu faktor penting dalam realisasi keadilan dalam pemberian upah. 
4) Kondisi - Kondisi Pekerjaan

Orang yang bekerja di daerah terpencil atau dilingkungan pekerjaan yang berbahaya harus memperoleh upah yang lebih besar dari pada mereka yang bekerja didaerah yang ada tempat - tempat hiburan atau dilingkungan pekerjaan yang tidak berbahaya.

\subsection{Konsep Kinerja}

\subsubsection{Pengertian Kinerja}

Menurut Armstrong dan Baron dalam Irham Fahmi (2012 : 7) Kinerja merupakan hasil pekerjaan yang mempunyai hubungan kuat dengan tujuan strategis organisasi, kepuasan konsumen, dan memberikan kontribusi pada ekonomi.

\subsubsection{Faktor - faktor Kinerja}

Menurut Gibson, Ivancevich, dan Donnely dalam Wibowo (2010 : 11) menyatakan bahwa faktor -faktor yang mempengaruhi kinerja pegawai adalah sebagai berikut :

1) Variabel Individu

Variabel individu meliputi kemampuan dan keterampilan baik fisik maupun mental, latar belakang, seperti keluarga, tingkat sosial dan pengalaman, demografi, menyangkut umur, asal usul dan jenis kelamin.

2) Variabel Psikologis

Variabel psikologis meliputi persepsi, kepribadian, sikap, belajar, dan motivas.

3) Variabel Organisasi

Variabel Organisasi meliputi sumber daya, kepemimpinan, imbalan, struktur, dan desain pekerjaan.

\subsubsection{Indikator Kinerja}

Menurut Hasibuan (2014 : 39), indikator pengukuran kinerja pegawai terdiri dari :

1.) Kuantitas

Kuantitas adalah besarnya volum atau beban kerja pegawai.

2.) Kualitas

Kualitas adalah tanggung jawab moral terhadap kualitas kerja.

3.) Personality

Personality merupakan kepribadian masing - masing pegawai.

4.) Ketepatan waktu

Ketepatan waktu adalah adanya penerapan disiplin waktu terhadap pegawai.

\subsubsection{Penilaian Kinerja}

Penilaian kinerja pada dasarnya merupakan kegiatan manusia dalam mencapai tujuan organisasi. Menurut Bintaro dan Daryanto (2017 : 66) mengungkapkan penilaian kinerja sebagai penentu secara periodik efektifitas operasional suatu kriteria yang telah ditetapkan sebelumnya. Karena pada dasarnya, suatu organisasi dioperasikan oleh sumber daya manusia, maka penilaian manusia dalam melaksanakan peran yang mereka mainkan dalam organisasi.

Setiap organisasi mengharapkan kinerja yang memberikan konstribusi untuk menjadikan organisasi sebagai suatu institusi yang unggul dikelasnya. Apabila keberhasilan organisasi untuk mengadakan institusi yang unggul, ditentukan oleh berbagai faktor (succes factor), maka faktor inilah yang digunakan sebagai pengukur keberhasilan personal. Dengan demikian dibutuhkan suatu penilaian kinerja yang dapat digunakan sebagai landasan untuk mendesain sistem penghargaan agar personel menghasilkan kinerjanya yang sejalan dengan kinerja yang diharapkan organisasi.

\subsection{Hubungan Teori Disiplin Kerja dan Kinerja}

Hubungan antara disiplin kerja dan kinerja pegawai yang didukung oleh teori menurut Hasibuan (2014 : 193), kedisiplinan sebagai bentuk kesediaan seorang pegawai untuk mentaati semua peraturan perusahaan dan norma - norma sosial yang berlaku. Adanya peraturan dan norma sosial di perusahaan akan menciptakan kedisiplinan kerja pada pegawai. Maka, akan 
berdampak baik pula pada kinerja pegawai dalam suatu peruasahaan. Dengang adanya teori ini maka dapat disimpulkan bahwa antara disiplin kerja dan kinerja pegawai saling berhubungan.

\subsection{Hubungan Teori Kompensasi dan Kineja}

Menurut Robbins (2010:221), yang mempersiapkan suatu hubungan yang kuat antara kinerja dan kompensasi pegawai, jika motivasinya dioptimalkan. Salah satu bukti yang mendukung pentingnya hubungan tersebut yaitu dengan diadakan suatu studi penelitian terhadap 400 perusahaan manufaktur pada tingkat pegawai operasional, menemukan bahwa perusahaan dengan program insentif upah dapat mencapai produktivitas $43 \%$ samapai $64 \%$ lebih besar dibandingkan dengan perusahaan tanpa program kompensasi seperti itu. Oleh karena itu, salah satu faktor yang dapat mendorong peningkatan kinerja pegawai dapat dipengaruhi dengan pemberian kompensasi.

\subsection{Hubungan teori Disiplin Kerja, Kompensasi dan Kinerja}

Disiplin kerja merupakan alat yang digunakan para manajer untuk berkomunikasi dengan pegawai agar mereka bersedia untuk mengubah suatu perilaku serta sebagai suatu upaya untuk meningkatkan kesadaran dan kesediaan seseorang menaati semua peraturan perusahaan dan norma - norma sosial yang berlaku. Disiplin yang diharapkan perusahaan. Pegawai pada dasarnya ada dua, yaitu mematuhi segala peraturan yang berlaku, dan menjauhi segala larangan yang berlaku dalam perusahaan. Pegawai akan dapat melakukan pekerjaan dengan baik, menaati segala peraturan yang berlaku, tidak pernah mangkir atau terlambat kerja, dan sebagainya apabila perusahaan dapat memberikan kompensasi (balas jasa) yang layak.

Dengan adanya pemberian kompensasi tersebut, maka semua pegawai akan dapat menyelesaikan pekerjaan yang menjadi tanggung jawab. Pegawai yang tergolong potensial akan dapat mengembangkan potensi dirinya untuk menghasilkan pekerjaan yang lebih berkualitas dan dapat meningkatkan kinerjanya.

\subsection{Penelitian Terdahulu}

Tabel 2.1

Penelitian Terdahulu

\begin{tabular}{|c|c|c|c|c|c|}
\hline No & $\begin{array}{c}\text { Nama } \\
\text { Penelitian }\end{array}$ & Judul Penelitian & Variabel & Indikator & Hasil \\
\hline 1. & $\begin{array}{l}\text { Reza Nurul } \\
\text { Ichan (2020) }\end{array}$ & $\begin{array}{l}\text { Pengaruh Disiplin } \\
\text { kerja terhadap } \\
\text { Kinerja }\end{array}$ & $\begin{array}{l}\text { Disiplin Kerja } \\
\text { (X1) } \\
\\
\\
\text { Kinerja } \\
\text { (Y) }\end{array}$ & $\begin{array}{l}\text { 1. Tujuan dan Kemampuan } \\
\text { 2. Terhadap pimpinan } \\
\text { 3. Balas Jasa } \\
\text { 4. Keadilan } \\
\text { 5. Pengawasan } \\
\text { 6. Sanksi Hukuman } \\
\text { 7. Ketegasan } \\
\text { 8. Hubungan Kemanusiaan } \\
\text { 1. Kuantitas } \\
\text { 2. Kualitas } \\
\text { 3. Personality } \\
\text { 4. Ketepatan Waktu }\end{array}$ & $\begin{array}{l}\text { Hasil penelitian } \\
\text { menunjukkan ada } \\
\text { pengaruh } \\
\text { signifikan antara } \\
\text { disiplin kerja PNS } \\
\text { terhadap kinerja } \\
\text { dengan hasil } \\
84,8 \% \text {. Pengaruh } \\
\text { cukup besar ini } \\
\text { menunjukkan } \\
\text { bahwa apabila } \\
\text { disiplin kerja } \\
\text { diterapkan akan } \\
\text { menghasil kan } \\
\text { kinerja pegawai } \\
\text { juga tinggi. }\end{array}$ \\
\hline
\end{tabular}




\subsection{Kerangka Pemikiran}

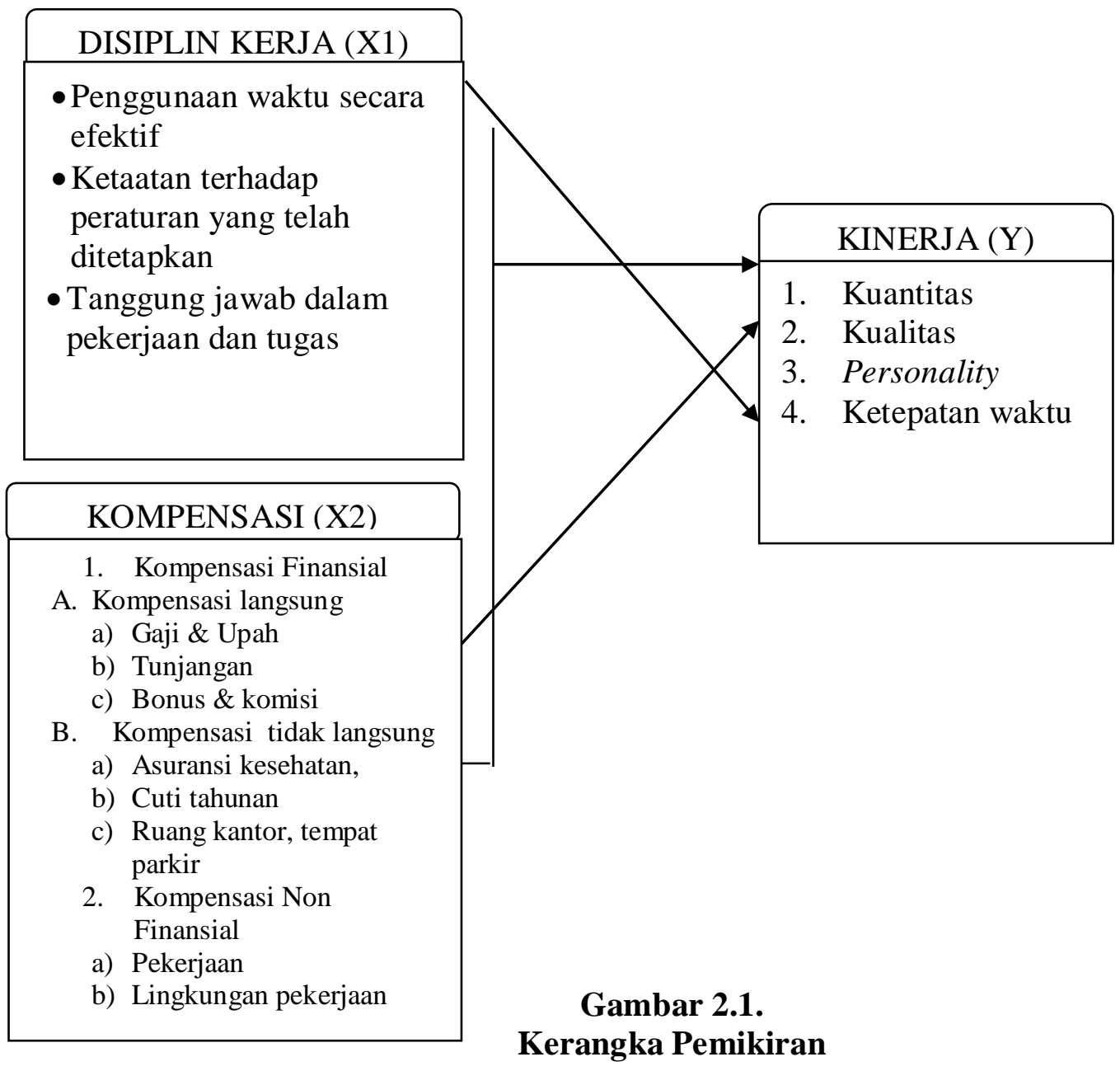

\subsection{Hipotesis}

H1 : Disiplin Kerja berpengaruh Terhadap Kinerja Pegawai Badan Kepegawaian dan Pengembangan SDM.

H2 : Kompensasi berpengaruh Terhadap Kinerja Pegawai Badan Kepegawaian dan Pengembangan SDM.

H3 : Disiplin Kerja dan Kompensasi berpengaruh Terhadap Kinerja Pegawai Badan Kepegawaian dan Pengembangan SDM.

\subsection{Uji Asumsi Klasik}

\subsubsection{Uji Normalitas}

\begin{tabular}{|c|c|c|}
\hline \multicolumn{3}{|c|}{ One-Sample Kolmogorov-Smirnov Test } \\
\hline & & $\begin{array}{l}\text { Unstandardized } \\
\text { Residual }\end{array}$ \\
\hline \multicolumn{2}{|l|}{$\mathrm{N}$} & 37 \\
\hline \multirow{2}{*}{ Normal Parameters ${ }^{\mathrm{a}, \mathrm{b}}$} & Mean & .0000000 \\
\hline & Std. Deviation & 1.44068059 \\
\hline \multirow[t]{3}{*}{ Most Extreme Differences } & Absolute & .118 \\
\hline & Positive & .075 \\
\hline & Negative & -.118 \\
\hline \multicolumn{2}{|l|}{ Test Statistic } & .118 \\
\hline \multicolumn{2}{|l|}{ Asymp. Sig. (2-tailed) } & $.200^{\mathrm{c}, \mathrm{d}}$ \\
\hline \multicolumn{3}{|c|}{ a. Test distribution is Normal. } \\
\hline \multicolumn{3}{|c|}{ b. Calculated from data. } \\
\hline \multicolumn{3}{|c|}{ c. Lilliefors Significance Correction. } \\
\hline \multicolumn{3}{|c|}{ d. This is a lower bound of the true significance. } \\
\hline
\end{tabular}


3.1.2. Uji Multikolinieritas

\begin{tabular}{|c|c|c|c|c|c|c|c|c|}
\hline \multicolumn{9}{|c|}{ Coefficients $^{a}$} \\
\hline \multirow{2}{*}{\multicolumn{2}{|c|}{ Model }} & \multicolumn{2}{|c|}{ Unstandardized Coefficients } & \multirow{2}{*}{\begin{tabular}{c|}
$\begin{array}{c}\text { Standardized } \\
\text { Coefficients }\end{array}$ \\
Beta \\
\end{tabular}} & \multirow[b]{2}{*}{$\mathrm{t}$} & \multirow[b]{2}{*}{ Sig. } & \multicolumn{2}{|c|}{ Collinearity Statistics } \\
\hline & & $\mathrm{B}$ & Std. Error & & & & Tolerance & VIF \\
\hline \multirow[t]{3}{*}{1} & (Constant) & 12,946 & 7,396 & & 1,750 & 0,089 & & \\
\hline & Dispiln Kerja & 0,298 & 0,107 & 0,398 & 2,780 & 0,009 & 0,949 & 1,054 \\
\hline & Kompensasi & 0,392 & 0,162 & 0,346 & 2,419 & 0,021 & 0,949 & 1,054 \\
\hline
\end{tabular}

\subsubsection{Uji Heterokesdasitas}

\begin{tabular}{|c|c|c|c|c|c|c|c|c|}
\hline \multicolumn{9}{|c|}{ Coefficients $^{\mathrm{a}}$} \\
\hline \multirow[b]{2}{*}{ Model } & & \multicolumn{2}{|c|}{ Unstandardized Coefficients } & $\begin{array}{c}\text { Standardized } \\
\text { Coefficients }\end{array}$ & \multirow[b]{2}{*}{$t$} & \multirow[b]{2}{*}{ Sig. } & \multicolumn{2}{|c|}{ Collinearity Statistics } \\
\hline & & \begin{tabular}{c|}
$\mathrm{B}$ \\
\end{tabular} & Std. Error & Beta & & & Tolerance & VIF \\
\hline \multirow[t]{3}{*}{1} & (Constant) & $-7,682 \mathrm{E}-16$ & 7,396 & & 0,000 & 1,000 & & \\
\hline & Dispiln Kerja & 0,000 & 0,107 & 0,000 & 0,000 & 1,000 & 0,949 & 1,054 \\
\hline & Kompensasi & 0,000 & 0,162 & 0,000 & 0,000 & 1,000 & 0,949 & 1,054 \\
\hline
\end{tabular}

\subsection{Analisis Regresi Linier Berganda}

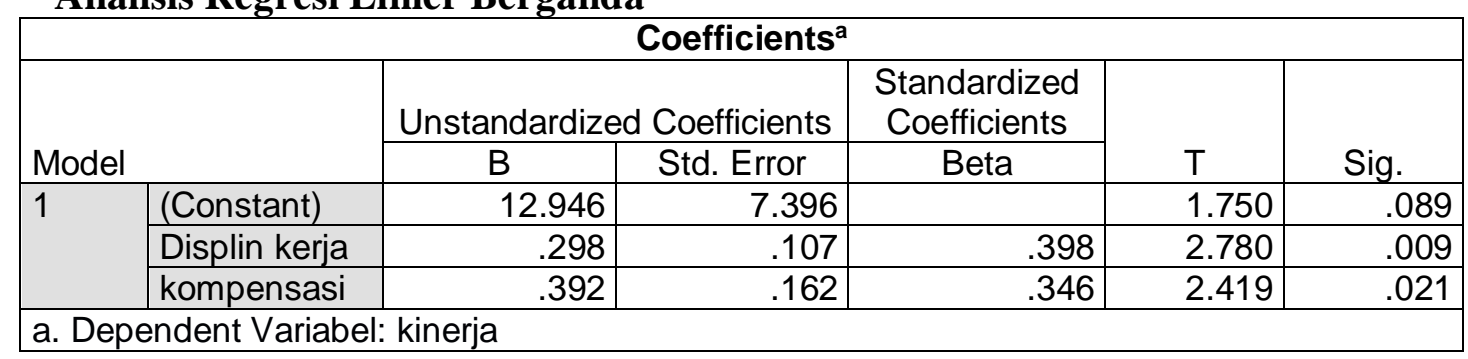

\subsection{Uji F (Simultan)}

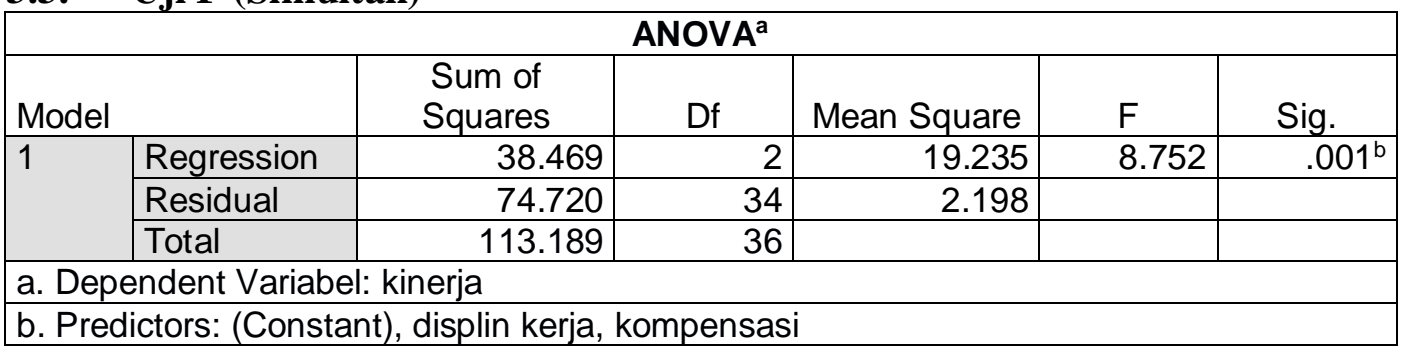

\subsubsection{Uji t (Parsial)}

\begin{tabular}{|c|c|c|c|c|c|c|}
\hline \multicolumn{7}{|c|}{ Coefficients $^{a}$} \\
\hline \multirow{2}{*}{\multicolumn{2}{|c|}{ Model }} & \multicolumn{2}{|c|}{ Unstandardized Coefficients } & \multirow{2}{*}{$\begin{array}{c}\text { Standardized } \\
\text { Coefficients } \\
\text { Beta }\end{array}$} & \multirow[b]{2}{*}{$\mathrm{T}$} & \multirow[b]{2}{*}{ Sig. } \\
\hline & & $\mathrm{B}$ & Std. Error & & & \\
\hline 1 & (Constant) & 12.946 & 7.396 & & 1.750 & .089 \\
\hline & Displinkerja & .298 & .107 & .398 & 2.780 & .009 \\
\hline & Kompensasi & .392 & .162 & .346 & 2.419 & .021 \\
\hline
\end{tabular}

\subsubsection{Uji Koefisien Determinasi $\left(\mathbf{R}^{2}\right)$}

\begin{tabular}{l|l|r|r|r|}
\hline \multicolumn{5}{|c|}{ Model Summary } \\
\hline Model & $\mathrm{R}$ & $\mathrm{R}$ Square & $\begin{array}{c}\text { Adjusted R } \\
\text { Square }\end{array}$ & $\begin{array}{c}\text { Std. Error of } \\
\text { the Estimate }\end{array}$ \\
\hline 1 & $.583^{\mathrm{a}}$ & .340 & .301 & 1.482 \\
\hline \multicolumn{5}{|c|}{ Predictors: (Constant), displin kerja, kompensasi } \\
Dependent Variabel : Kinerja Pegawai
\end{tabular}




\subsection{Pembahasan}

Berdasarkan hasil penelitian secara statistik dapat dilihat dari jenis kelamin diketahui dari 37 responden, sebanyak 23 orang atau $62,1 \%$ berjenis laki - laki dan responden perempuan sebanyak 14 orang dengan proporsi 34,1\%. Sehingga dapat disimpulkan jumlah responden laki -laki lebih banyak dari pada responden perempuan. Dan adapun berdasarkan umur dari pegawai bahwa kelompok terbanyak adalah responden pada interval umur 31 - 40 tahun sebanyak 21 orang dengan proporsi $51,21 \%,>40$ tahun sebanyak 12 orang dengan proporsi 32,43\% sedangkan terendah 20 -30 tahun sebanyak 4 orang dengan proporsi 9,7\%. Dan hasil dari uji normalitas dengan Kolmogrov - simirnov Test diperoleh nilai Asymp.Sig (2-tailed) sebaesar 0,002. Nilai tersebut 0,05 yaitu 0,002 0,05 maka data tersebut berdistribusi normal sehingga asumsi normalitas terpenuhi. Dari hasil Uji Multikolinieritas Untuk mendeteksi ada atau tidaknya multikolinieritas di dalam model regresi dapat dilihat dari ni;ai tolerance dan variam Invloation Factor (VIF). Nilai cut off yang umum dipakai untuk menunjukkan adanya mulitikolinieritas adalah nilai tolerance $\leq 0,10$ atau sama dengan nilai VIF $\geq 10$. Dan dari hasil Uji Heterokesdasitas Berdasarkan output uji heterokesdasitas diperoleh nilai Sig semua variabel bebas yakni disiplin kerja $\left(\mathrm{X}_{1}\right)$ dan kompensasi $\left(\mathrm{X}_{2}\right)$ sebesar 1,$000 ; 1,000$. Nilai tersebut mengimplementasikan bahwa tidak terjadi heterokesdasitas karena nilai Sig. ${ }^{-} 0,05$. Dan hasil dari analisis regresi linier berganda $\mathbf{Y}=\mathbf{a}+\mathbf{b}_{1} \mathbf{X}_{\mathbf{1}}+\mathbf{b}_{\mathbf{2}} \mathbf{X}_{2}+\mathbf{e}$

$Y=12.946+0,298 X_{1}+0,392 X_{2}+7,396$

a. Konstanta sebesar 12,9 mempunyai arti bahwa ketika variabel disiplin kerja dan kompensasi dalam kondisi konstan, maka kinerja pegawai nilainya adalah 12,9.

b. Koefisien regresi variabel disiplin kerja sebesar 0,298 dan memiliki tanda koefisien regresi positif, artinya jika variabel independen lain nilainya tetap dan variabel disiplin mengalami kenaikan sebanyak satu - satuan, maka kinerja pegawai akan meningkat sebesar 0,298.

Koefisien regresi variabel kompensasi sebesar 0,392 dan memiliki tanda koefisien regresi positif, artinya jika variabel independen lain nilainya tetap dan nilai variabel kompensasi mengalami kenaikan satu - satuan maka kinerja pegawai meningkatkan 0,392 Dari hasil uji $\mathrm{F}$ dapat dilihat bahwa F-hitung (F-statistic) sebesar 8,752 lebih besar dari $\mathrm{F}_{\text {tabel }}$ yaitu 3,28 dengan nilai probabilitas 0,001 yang berarti dibawah nilai signifikansi 0,05 , maka, $\mathrm{H}_{0}$ ditolak dan $\mathrm{H}_{1}$ diterima yang berarti variabel independen disiplin kerja dan kompensasi secara simultan (bersama - sama) memiliki pengaruh terhadap kinerja Pegawai. Dan hasil dari Uji T Untuk variabel $\mathrm{X}_{2}$ yakni kompensasi diperoleh nilai t hitung sebesar 2,419 dan nilai Sig 0,021. Nilai $\mathrm{t}$ hitung- $\mathrm{t}$ tabel yaitu 2,419 2,780 dan nilai $\mathrm{Sig}^{-}$. 0,05 yaitu $0,021^{-} 0,05$ maka $\mathrm{H}_{0}$ diterima dan $\mathrm{H}_{1}$ ditolak yang berarti bahwa tidak terdapat pengaruh signifikan secara parsial antara variabel $\mathrm{X}_{2}$ yakni kompensasi terhadap kinerja pegawai di Badan Kepegawaian dan Pengembangan SDM Kabupaten Musi Banyuasin. Dan hasil dari Uji Koefisien Determinasi $\left(\mathrm{R}^{2}\right)$ bahwa nilai koefisien korelasi R Square sebesar 0,340 atau 34,0\%. Hasil ini menunjukkan bahwa terdapat pengaruh anatara variabel ddisiplin kerja dan kompensasi terhadap variabel kinerja pegawai. Hal ini menunjukkan bahwa persentase pengaruh variabel disiplin kerja dan kompensasi terhadap kinerja pegawai hanya sebesar 34,0\%. Sedangkan sisanya sebesar $66 \%$ dipengaruhi oleh variabel - variabel lain diluar model estimasi penelitian ini.

\subsection{Implementasi Hasil}

Berdasarkan hasil uji hipotesis (uji t) Disiplin kerja secara parsial berpengaruh terhadap kinerja pegawai Badan Kepegawaian dan Pengembangan SDM Kabupaten Musi Banyuasin. Hasil yang diperoleh disiplin kerja memiliki nilai $t$ hitung sebesar 2,780 > t tabel 2,419 dan tingkat signifikan $\mathrm{t}$ lebih kecil dari 0,05 (Sig.t $=0,009<0,05) . \mathrm{Maka}_{1}$ dalam penelitian ini "disiplin kerja mempunyai pengaruh terhadap kinerja pegawai" terbukti kebenarannya atau artinya $\mathrm{H}_{1}$ diterima dan $\mathrm{H}_{0}$ ditolak. Hasil penelitian ini sejalan dengan hasil penelitian M. Harli 
(2010) yang menyatakan bahwa secara parsial disiplin kerja berpengaruh terhadap kinerja pegawai. Badan Kepegawaian dan Pengembangan SDM memberikan ketegasan sanksi terhadap seluruh pegawai yang tidak disiplin dalam bekerja yaitu dengan adanya pemotongan gaji terhadap pegawai yang tidak disiplin tersebut, namun pada kenyataanya masih banyak pegawai yang melakukan ketidak disiplinan tanpa mengiraukan ketegasan sanksi tersebut.

\subsection{Simpulan}

1. Dari Hasil penelitian didapat hasil $t_{\text {hitung }}$ untuk variabel $\mathrm{X}_{1}$ yakni disiplin kerja adalah sebesar 2,780 > dari $\mathrm{t}_{\text {tabel }} 1.687$ maka $\mathrm{H}_{0}$ ditolak dan $\mathrm{H}_{1}$ diterima yang berarti bahwa terdapat pengaruh disiplin kerja terhadap kinerja pegawai Badan Kepegawaian dan Pengembangan SDM Kabupaten Musi Banyuasin.

2. Dari hasil penelitian diperoleh nilai t hitung Untuk variabel $\mathrm{X}_{2}$ yakni kompensasi adalah sebesar 2,419 > dari t tabel 1,687 maka $\mathrm{H}_{0}$ diterima dan $\mathrm{H}_{1}$ ditolak yang berarti bahwa berpengaruh variabel $\mathrm{X}_{2}$ yakni kompensasi terhadap kinerja pegawai di Badan Kepegawaian dan Pengembangan SDM Kabupaten Musi Banyuasin.

3. Dari Hasil penelitian didapat hasil F-hitung $\left(F\right.$-statistic) sebesar 8,752 karena $F_{\text {hitung }}$ lebih besar dari $F_{\text {tabel }}$ yaitu 3,28 dengan nilai probabilitas 0,001 yang berarti dibawah nilai signifikansi 0,05 , maka, $\mathrm{H}_{0}$ ditolak dan $\mathrm{H}_{3}$ diterima yang berarti variabel independen disiplin kerja dan kompensasi secara simultan (bersama - sama) memiliki pengaruh terhadap kinerja Pegawai.

\subsection{Saran}

1. Bagi Peneliti Selanjutnya yang tertarik untuk menguji aspek yang serupa yaitu disiplin kerja, kompensasi dan kinerja pegawai diharapkan untuk mengembangkan penelitian ini dengan menggunakan populasi dan sampel yang lebih luas agar hasil penelitian lebih teruji andalannya. Di samping itu, diharapkan untuk menguji variabel lain yang diduga kuat dapat mempengaruhi kinerja pegawai seperti kepuasan, sikap, perilaku, pelatihan dan kemauan untuk bekerja.

2. Bagi pihak kantor BKPSDM Kabupaten Musi Banyuasin, agar lebih memperhatikan disiplin kerja dan kompensasi dalam upaya untuk meningkatkan kinerja pegawai. Karena kedua hal tersebut apabila diterapkan dengan baik akan meningkatkan kinerja pegawai. Namun disarankan kepada kantor BKPSDM agar lebih memfokuskan kepada pemberian kompensasi. Hal ini Karena kompensasi dinilai lebih berpengaruh terhadap kinerja pegawai dibandingkan dengan disiplin kerja. Kompensasi yang perlu diperhatikan kantor BKPSDM dalam hal ini yaitu kompensasi dalam bentuk insentif (bonus), yang dinilai lebih efektif dalam meningkatkan kinerja pegawai.

\section{DAFTAR PUSTAKA}

Armstrong dan Baron dalam Irfan Fahmi. 2012. Manajemen Kinerja. Jakarta.

Bintaro dan Daryanto. 2017. Manajemen Penilaian Kinerja Pegawai. Yogjakarta : Gava Media Griffin, Jill. 2010. Menumbuhkan dan Mempertahankan Kesetiaan Pelanggan. Alih Bahasa

Dwi Krtini Yahya. Jakarta : Erlangga.

Gibson, James., L., Jhon M., Ivancevich., dan H. Donnelly., Jr. 2010. Organisasi dan Manjemen, Perilaku, Struktur, dan Proses, terjemahan oleh Joerban Wahid, Erlangga, Jakarta.

Hasan, Iqbal. 2012. Pokok-Pokok Materi Statistik I (Statistik Deskriptif). Jakarta : Bumi Aksara Hasibuan, Malayu S.P. 2016. Manajemen Sumber Daya Manusia. Jakarta: Bumi Aksara Jakarta. 
Handoko, T. Hani. 2010. Manajemen Personalia dan Sumber Daya Manusia. Yogjakarta.

Imas, Yohny Emron. 2016. Manajemen Sumber Daya Manusia Strategi dan perubahan dalam rangka meningkatkan kinerja pegawai dan organisasi. Bandung : Alfabeta Bandung.

Joko, Sarwanto. 2016. Pengaruh Disiplin Kerja Terhadap Kinerja Pegawai. Yogjakarta : UIN Sunan Klijaga.

Kismono, Gugup. 2011. Bisnis Pengantar. Fakultas Ekonomi dan Bisnis UGM. Yogjakarta.

Priyanto, Duwi. 2012. Cara Kilat Belajar Analisis Data dengan SPSS. Yogjakarta : C.V. ANDI

Rivai, Rusdy A. 2009. Manajemen. Palembang: Fakultas Ekonomi Universitas Muhammadiyah.

Robbins, P. Stephen dan Mary Coulter. 2010. Manajemen, diterjemahkan oleh Bob Sabran, Wibi Hardani. Erlangga : Jakarta.

Santos, Singgih. 2016. Panduan Lengkap SPSS. Jakarta : Elekmedia Computindo.

Siregar, Syofian. 2010. Statistik Deskriptif Untuk Penelitian. Jakarta : Pt Rajagrafindo Persada.

Siregar, Syofian. 2015. Statistik Parametrik Untuk Penelitian Kuantitatif: Dilengkapi dengan Perhitungan Manual dan Aplikasi SPSS. Jakarta: Bumi Aksara.

Sunyoto, Danang. 2014. Penelitian Sumber Daya Manusia. Jakarta : Buku Seru.

Sutrisno, Edy. 2014. Manajemen Sumber Daya Manusia. Jakarta: Kencana - Prenda Media Group.

Sugiyono. 2012. "Memahami Penelitian Kualitatif”. Bandung : Alfabeta.

Sujarweni, V. Wiratna. 2014. Metode Penelitian: Lengkap, Praktis dan Mudah Dipahami. Yogjakarta: Pustaka Baru Press.

Suparyadi. 2015. Manajemen Sumber Daya Manusia. Yogjakarta : Andi.

Terry, George R. 2011. Prinsip-Prinsip Manajemen. Terjemahan J. Smith D.F.M Jakarta : Bumi Aksara

Wibowo. 2014. Manajemen Kinerja. Edisi Keempat. Jakarta: Rajawali Pers. PT. Raja Grafindo 